\title{
$\mathrm{FBG}$ 광섬유센서가 내장된 7연 강연선을 이용한 포스트텐션 UHPC 교량의 긴장력 장기모니터링
}

\author{
김 현 우 ${ }^{1} \cdot$ 김 재 민 $^{2^{+}} \cdot$ 최 송 이 $^{3} \cdot$ 박 성 용 $^{4} \cdot$ 이 환 우 $^{5}$ \\ ${ }^{1}$ 한국시설안전공단 특수교유지관리센터, ${ }^{2}$ 전남대학교 해양토목공학과, ${ }^{3}$ 전남대학교 건설환경공학과,

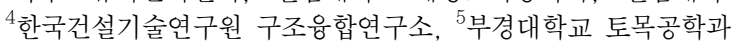

\section{Long Term Monitoring of Prestressing Tension Force in Post-Tension UHPC Bridge using Fiber Optical FBG Sensor}

\author{
Hyun-Woo Kim ${ }^{1}$, Jae-Min Kim ${ }^{2 \dagger}$, Song-Yi Choi ${ }^{3}$, Sung-Yong Park ${ }^{4}$ and Hwan-Woo Lee ${ }^{5}$ \\ ${ }^{1}$ Long Span Bridge Management Center, Korea Infrastructure Safety and Technology Corporation, Yeosu, 59768, Korea \\ ${ }^{2}$ Department of Marine and Civil Engineering, Chonnam National Univ., Yeosu, 59626, Korea \\ ${ }^{3}$ Department of Civil and Environmental Engineering(Graduate School), Chonnam National Univ., Yeosu, 59626, Korea \\ ${ }^{4}$ Division of Structural Engineering Research, Korea Institute of Construction and Building Technology, Goyang, 10223, Korea \\ ${ }^{5}$ Department of Civil Engineering, Pukyong National Univ., Busan, 48547, Korea
}

\begin{abstract}
This paper presents results of one-year monitoring on prestressing force of a 7-wire steel post-tensioning strand which is installed in a UHPC(ultra high performance concrete) bridge with $11.0 \mathrm{~m}$ long, $5.0 \mathrm{~m}$ wide, and $0.6 \mathrm{~m}$ high by using a FBG-encapsulated 7-wire steel strand. The initial prestressing forces and the prestress changes during a vehicle load test were measured using the FBG-encapsulated strand. The results show that the FBG-encapsulated 7-wire strand is very effective for monitoring the prestress forces even the change in the tension force is very small. Additionally, it was indicated that selection of the thermal expansion coefficient which is used for the temperature correction shall be carefully carried out.
\end{abstract}

Keywords : FBG sensor, PSC grider, prestressing strand, tension force monitoring, temperature compensation

\section{1. 서 론}

최근 토목시설물은 설계·시공기술, 해석기술, 재료기술 등의 발달로 구조물이 대형화 및 슬림화되고 있다. 이와 더 불어 최근에는 구조물의 유지관리에 대한 관심이 높아지면 서 구조물의 건전성 모니터링(SHM, Structural Health Monitoring)과 이를 평가하기 위한 다양한 연구들이 진행되 고 있으며, 실제 구조물에도 다양한 모니터링 기술들이 적용 되고 있다(Maaskant et al., 1997; Hong et al., 2000; Zhou and Ou 2004; Tennyson et al., 2001).

$\mathrm{SHM}$ 에서 활용되고 있는 센서들 중 하나인 광섬유센서 (optical fiber sensor)는 기존의 전기적인 신호를 이용하는

\footnotetext{
${ }^{+}$Corresponding author:

Tel: +82-61-659-7245; E-mail: jm4kim@jnu.ac.kr

Received October 17 2015; Revised November 23 2015;

Accepted November 242015

C) 2015 by Computational Structural Engineering Institute of Korea
}

전기저항식 센서와 달리 빛의 굴절률 변화를 이용하므로 전 자기파의 영향이 없으며, 크기가 작고 내구성 및 민감도가 우수하여 많은 연구들이 진행되고 있다. 특히, 광섬유센서 중 FBG(Fiber Bragg Grating)센서는 다양한 물리량 측정이 가능하고, 하나의 선으로 여러 측점을 측정할 수 있는 장점 등 으로 여려 분야에서 활용되고 있다(Udd 1996, Lau 2003, Calvert and Mooney 2004, Ren et al., 2005; Kim et al., 2012).

$\mathrm{FBG}$ 센서를 활용한 구조물 긴장력 측정에 대한 연구들은 긴장부재 외부에 부착하거나, 로드셀(load cell) 정착부에 센서를 삽입하여 일체화시키는 방법, Strand와 유사한 신소 재에 센서를 결합하는 등의 연구가 진행되었다(Nellen et

This is an Open-Access article distributed under the terms of the Creative Commons Attribution Non-Commercial License(http://creativecommons. org/licenses/by-nc/3.0) which permits unrestricted non-commercial use, distribution, and reproduction in any medium, provided the original work is properly cited. 
al., 1999; Zhou et al., 2005; Zhang et al., 2006; Inaudi, 2009; Xuan et al., 2009; Kim et al., 2015). 하지만 기존의 연구 방법들은 구조물 긴장부재 또는 주요부 재의 외부에 설치하여 계측함으로써 콘크리트 내부 긴장부 재의 긴장력 또는 프리스트레스를 측정하기에는 어려운 단 점이 있다. 이러한 문제점을 개선하기 위해 $\operatorname{Kim}$ 등(2010, 2012)은 현장에서 긴장부재로 많이 사용되고 있는 7연 강연 선에 센서를 삽입하여 부재 및 센서의 역할을 동시에 수행하 는 긴장력 계측 방법을 소개하고 콘크리트 내부 긴장력을 계 측하는 연구를 수행하였다.

이 연구에서는 $\mathrm{FBG}$ 센서를 내장한 7연 강연선을 실제 포스 트텐션 $\mathrm{UHPC}$ 교량에 적용하여 도입 긴장력과 시공완료 후 콘크리트 내부 프리스트레스 변화에 대한 장기모니터링을 수 행하였다. 또한 현장에서 계측된 계측결과와 대기온도 계측정 보를 이용하여 $\mathrm{FBG}$ 센서를 내장한 7연 강연선의 온도보정계 수 산정방법을 도출하였다. 이로부터, 이 연구에서 사용한 강 연선의 긴장력 측정방법이 내부 프리스트레스 변화를 효과적 으로 측정할 뿐만 아니라, 장기적인 프리스트레스 손실에 대 한 모니터링과 온도보정 방법의 유효성을 제시하였다.

\section{FBG센서를 내장한 7연 강연선}

\subsection{FBG센서}

FBG센서는 일반 광섬유에 UV 레이저를 조사하여 Fig. 1 (a)와 같이 주기적인 격자를 생성하고 광섬유의 길이방향 굴절률을 변화시킴으로써 Fig. 1(b)와 같은 온도와 변형률에 반응하는 파장변화를 계측할 수 있는 광섬유센서이다. FBG 센서는 높은 민감도, 계측값의 선형성, 전자기간섭의 영향이 없고, 고온에 강하며, 하나의 선에 다지점측정 (multiplexing) 이 가능한 장점이 있다. 하지만 센서가 근본적으로 유리재질 로 이루어져 있어 취급 및 현장 적용시 쉽게 파손될 수 있으 므로 외부로부터 센서를 보호하는 것이 매우 중요하다.

Fig. 1(a)와 같은 FBG센서의 코어에 일정 대역의 빛 파 장스펙트럼을 입사시키면 브래그 격자 조건에 만족하는 파장 은 반사되고, 그 외 파장은 통과한다. 반사파장의 기준파장 $\left(\lambda_{b}\right)$ 은 식 (1)과 같이 광섬유의 굴절률 $\left(n_{e f f}\right)$ 과 격자간격 $(\Lambda)$ 에 따라 변하며 온도 및 변형률 변화로 인하여 격자의 간격 이 변화되고 이는 반사파장의 변화로 나타난다(Othonos and Kalli, 1999).

$$
\lambda_{b}=2 n_{e f f} \Lambda
$$

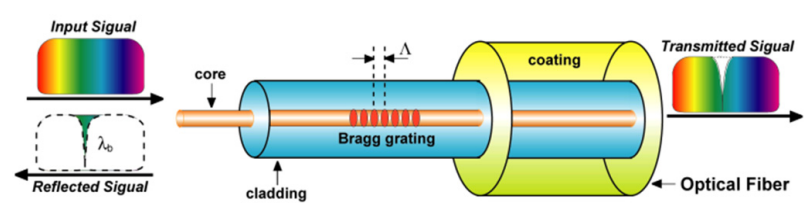

(a) Principle of FBG sensor

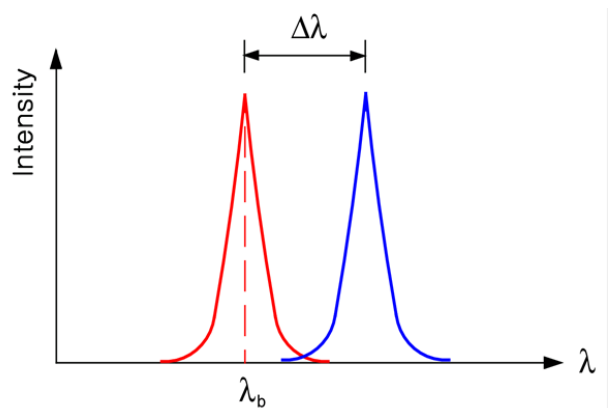

(b) Wavelength shift due to temperature and/or elastic strain change

Fig. 1 Fundamentals of FBG sensor

이때 반사파장의 변화 $(\Delta \lambda)$ 는 식 (2)와 같이 응력에 의한 유 효변형률 $(\Delta \varepsilon)$ 과 온도변화 $(\Delta T)$ 의 함수로 표현된다.

$$
\frac{\Delta \lambda}{\lambda_{b}}=\left(1-P_{e}\right) \Delta \varepsilon+(\alpha+\xi) \Delta T
$$

여기서, $P_{e}$ 는 광탄성상수로서 실리카인 경우 $0.22, \alpha$ 는 광 섬유의 열팽창계수로서 실리카인 경우 $\alpha \sim 0.5 \times 10^{-6} /{ }^{\circ} \mathrm{C}$ 이다. 이 논문에서는 이 연구에서 사용한 $\mathrm{FBG}$ 센서의 제작회사에 서 제공한 열팽창계수인 $0.51 \times 10^{-6} /{ }^{\circ} \mathrm{C}$ 를 사용하고 이 값을 $\alpha_{F B G}$ 로 표기하였다. 그리고 식 (2)에서 $\xi$ 는 온도에 의한 굴절률변화를 나타내는 열광학계수로서 Othonos와 Kalli (1999)에 따르면 게르마늄실리카 광섬유인 경우 8.60× $10^{-6} /{ }^{\circ} \mathrm{C}$ 로서 이 논문에서는 이 값을 $\xi_{\text {textbook }}$ 으로 표기하였다. 하지만 이 연구에서 사용한 $\mathrm{FBG}$ 센서의 제작회사에서는 $\xi$ 값 에 대한 실험결과를 제공하지 않아서 2.3절과 같은 온도실 험을 통해 실험적으로 $\xi$ 값을 결정하고 이 값을 $\xi_{F B G}$ 로 표 기하였다. 따라서 온도변화량과 광섬유의 온도계수 $(\alpha, \xi)$ 를 알고 있다면 $\mathrm{FBG}$ 센서로부터 계측된 파장변화를 이용하여 응력을 유발하는 유효변형률을 간단하게 계산할 수 있다.

\section{$2.2 \mathrm{FBG}$ 센서를 내장한 7 연 강연선}

$\mathrm{PSC}$ 교량에 사용되는 7연 강연선은 일반적으로 직경이 $12.7 \mathrm{~mm}(0.5 \mathrm{inch})$ 또는 $15.2 \mathrm{~mm}(0.6 \mathrm{inch})$ 로서 직선을 유지하는 킹와이어(king wire)에 6개의 와이어를 나선형으 로 결합하는 방법으로 제작되어 있다. 이 연구에서 사용한 

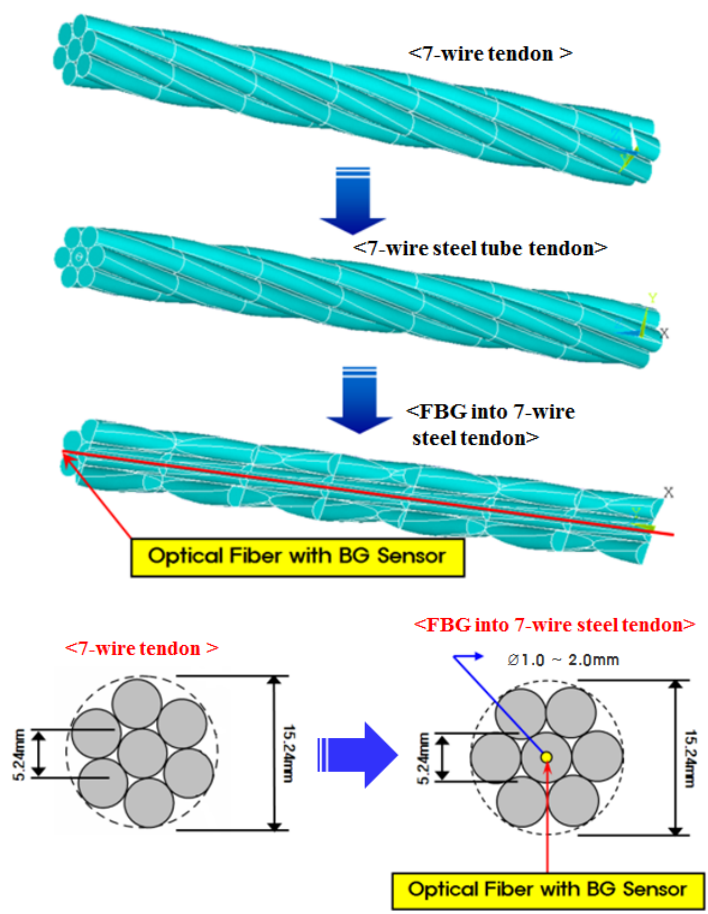

Fig. 2 Concept of in-strand FBG sensor

$\mathrm{FBG}$ 센서를 내장한 7 연 강연선은 Fig. 2와 같이 강제튜브 (steel tube) 내부에 $\mathrm{FBG}$ 센서를 삽입하고 접착제를 이용하 여 고정한 후 킹와이어를 $\mathrm{FBG}$ 센서 내장 튜브로 교체하여 제작된다. 이때 광섬유의 직경은 일반적으로 $1 / 4 \mathrm{~mm}$ 이고 강 제튜브의 내경은 $1.0 \mathrm{~mm} 2.0 \mathrm{~mm}$ 이며, 낮은 점성을 가진 접착제를 강제튜브에 충진하여 $\mathrm{FBG}$ 센서와 강제튜브를 일체 화시킨다.

킹와이어에 일체화된 $\mathrm{FBG}$ 센서는 장기 인장하중을 받을 경우 점착력 저하 및 분리현상이 발생할 수 있다. 따라서 접 착성능이 우수하면서도 점도가 낮고 경화시간이 충분히 길어 제작성이 우수한 접착제를 선택하여야 한다. 이와 관련된 $\operatorname{Kim}$ 등 $(2010,2012)$ 의 실내실험 연구결과 $\mathrm{FBG}$ 센서를 내 장한 7연 강연선의 긴장력 계측결과는 UTM 로드셀 계측결
과와 $5 \%$ 이내임을 보고하였다.

\section{$2.3 \mathrm{FBG}$ 센서의 온도계수}

$\mathrm{FBG}$ 센서는 온도에 대한 민감도가 우수하므로 온도센서로 사용시에 장점이 있지만 유효변형률 계측시에는 단점으로 작 용한다. 따라서 온도변화가 큰 경우에 $\mathrm{FBG}$ 센서를 유효변형 률 센서로 적용하기 위해서는 반드시 온도보정을 수행하여야 한다. FBG센서의 온도계수는 열팽창계수(식 (2)에서 $\alpha$ )와 열광학계수(식 (2)에서 $\xi$ )이다. 이 온도계수는 광섬유의 재 질과 제조방법에 따라 달라지며 일반적으로 열팽창계수 보다 는 열광학계수의 영향이 지배적이다.

이에 이 연구에 식 (2)에서 제시된 온도계수의 적용성과 연구에 적용된 $\mathrm{FBG}$ 센서의 온도계수를 재산정하기 위해 Fig. 3과 같이 항온항습기를 이용한 실내실험을 수행하였다. 온도실험은 항온항습기에서 최대 $40^{\circ} \mathrm{C}$ 의 온도변화에 따른 $\mathrm{FBG}$ 센서의 파장변화를 계측하였다. 이 실험에서 유효변형률 $(\Delta \varepsilon)$ 이 0 이므로 온도변화에 따른 파장변화는 온도계수에 의 한 영향만 존재한다. 따라서 항온항습기에서 온도변화량 $(\Delta T)$ 과 $\mathrm{FBG}$ 센서의 파장변화를 측정함으로써 $(\alpha+\xi)$ 값을 산정할 수 있다.

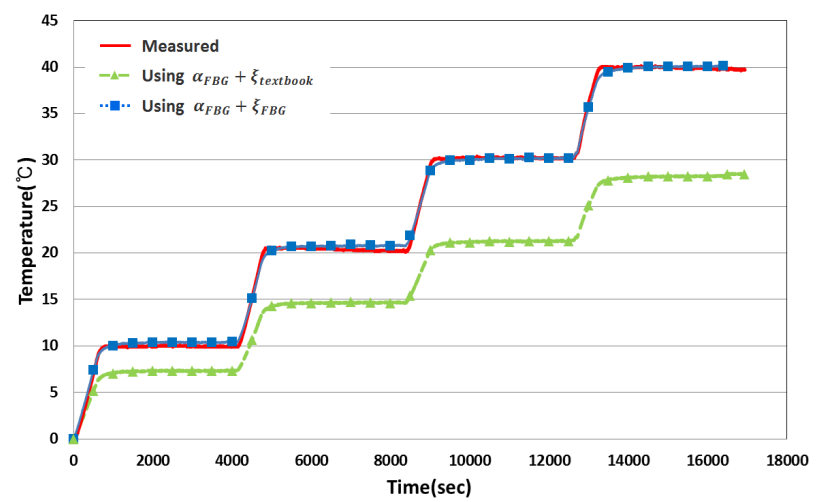

Fig. 4 Results of temperature test for FBG sensor

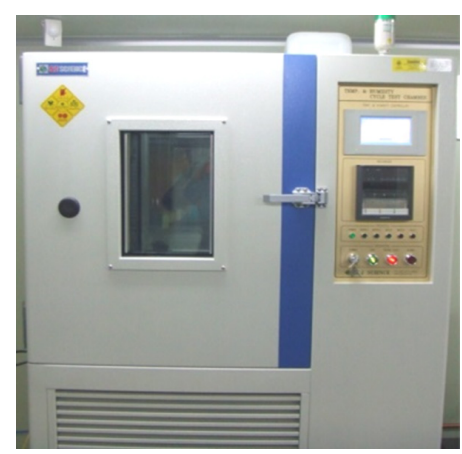

(a) Thermohygrostat

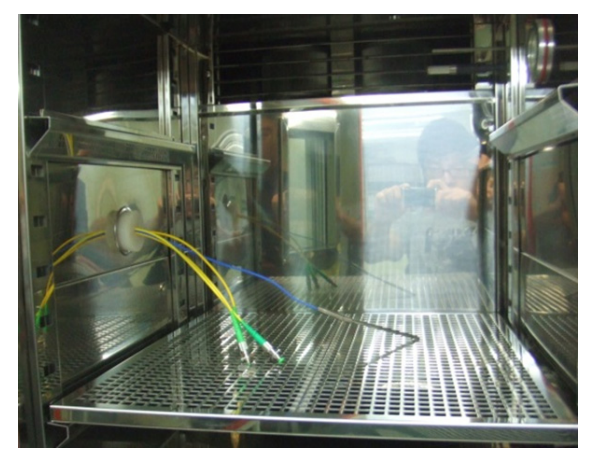

(b) Internal view of thermohygrostat

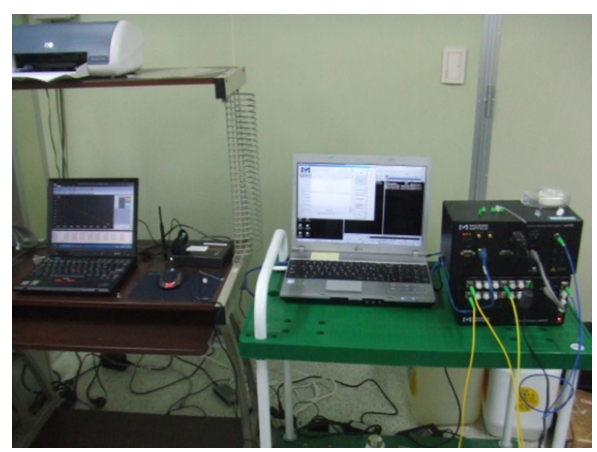

(c) FBG measurement system

Fig. 3 Temperature test using thermohygrostat 
$\mathrm{FBG}$ 센서의 열광학계수는 열팽창계수로 $\alpha_{F B G}$ 를 사용할 경우 $\xi_{F B G}=5.67 \times 10^{-6} /{ }^{\circ} \mathrm{C}$ 로 추정되었다. 추정된 온도계수 $\left(\alpha_{F B G}, \xi_{F B G}\right)$ 를 이용하여 $\mathrm{FBG}$ 센서 계측온도와 항온항습기 의 실측온도를 Fig. 4 에 비교하였다. 이 그림으로부터 알 수 있듯이 추정된 온도계수에 의한 보정값은 실측값과 매우 잘 일치한다. 반면에 $\alpha_{F B G}$ 와 $\xi_{t e x t b o o k}=8.60 \times 10^{-6} /{ }^{\circ} \mathrm{C}$ 를 적용하 여 추정한 온도변화는 실제값의 약 $70 \%$ 에 수준인 것으로 나 타났다. 이로부터 $\mathrm{FBG}$ 센서를 적용할 때 제작특성이 반영된 온도보정계수를 사용하는 것이 중요함을 알 수 있었다.

\section{3. 포스트텐션 UHPC 교량의 긴장력 모니터링}

\section{1 포스트텐션 UHPC 교량}

이 연구에 적용된 UHPC 교량은 길이 $11.0 \mathrm{~m}$, 폭 $5.0 \mathrm{~m}$, 높이 $0.6 \mathrm{~m}$ 의 포스트텐션 거더로서 Fig. 5 와 같이 3 개의 세 그먼트로 구성되어 있다. 각 세그먼트는 $90^{\circ} \mathrm{C}$ 이상의 증기양 생을 이용한 프리캐스트로 제작하였으며, 프리스트레스 적용 을 위해 직경 $15.2 \mathrm{~mm}$ 7연 강연선 7 가닥을 직선으로 설치 하고 포스트텐션방식으로 긴장력을 도입하였다.

$\mathrm{FBG}$ 센서가 내장된 7연 강연선을 중앙 세그먼트 우측 1 개소 덕트에 설치하였으며, 긴장력 도입 완료 후 내부에 모 르타르를 주입함으로써 거더와 일체화시켰다. 완성된 3개의 세그먼트는 설치현장으로 이동 및 가설하여 횡방향 강봉을 삽입 후 긴장함으로써 Fig. 6과 같은 $\mathrm{UHPC}$ 교량을 건설하 였다.

Table 1 Material properties of UHPC

\begin{tabular}{|c|c|}
\hline Material properties & Value \\
\hline Compressive strength $\left(f_{c k}\right)$ & $180 \mathrm{MPa}$ \\
\hline Modulus of elasticity $\left(E_{c}\right)$ & $45,000 \mathrm{MPa}$ \\
\hline Thermal expansion coefficient $\left(\alpha_{P S C}\right)$ & $1.35 \times 10^{-6} /{ }^{\circ} \mathrm{C}$ \\
\hline Poisson's ratio & 0.2 \\
\hline Unit weight & $25.5 \mathrm{kN} / \mathrm{m}^{3}$ \\
\hline
\end{tabular}

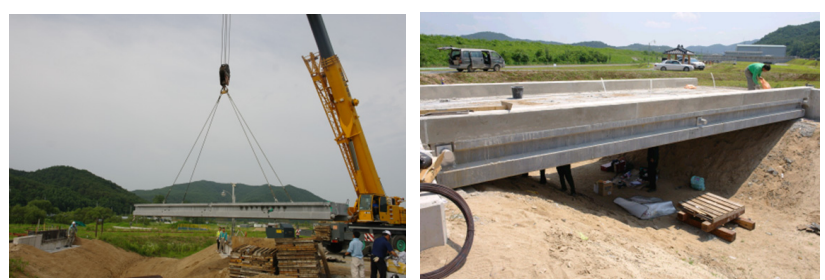

Fig. 6 Installation of the UHPC bridge

\section{$3.2 \mathrm{FBG}$ 센서 배치 및 도입 긴장력 계측}

$\mathrm{FBG}$ 센서를 내장한 강연선은 Fig. 7과 같이 길이 12.5 $\mathrm{m}$ 로 제작하였으며, 세그먼트 중앙지점과 긴장단(jacking end)의 긴장력을 계측할 수 있도록 2 개의 $\mathrm{FBG}$ 센서를 배치 하였다. 긴장력 도입은 긴장단에서 모노 인장젝을 이용하여 개별 긴장하였으며, $\mathrm{FBG}$ 센서를 내장한 강연선은 한 개 덕트 의 강연선 7 본 중 마지막으로 긴장하였다.

한 개 덕트의 설계 긴장력은 $1,328 \mathrm{kN}$ 으로 기존 강연선의 경우 $189.71 \mathrm{kN}\left(0.8 f_{p u}\right)$ 의 긴장력을 도입하였다. 하지만, $\mathrm{FBG}$ 센서를 내장한 강연선은 계측의 안전성과 센서의 성능 그리고 구조물의 거동에 큰 영향이 없는 범위를 고려하여 $154.65 \mathrm{kN}\left(0.65 f_{p u}\right)$ 의 긴장력을 도입하였다.

$\mathrm{FBG}$ 센서를 내장한 강연선을 이용한 도입 긴장력 계측결과 는 Fig. 8과 같다. 긴장력 도입 단부에 근접한 $\mathrm{BG1}$ 은 $164.26 \mathrm{kN}$ 으로 계측되어 설계 긴장력 대비 $6.51 \%$ 큰 힘이 도입되었으며, 세그먼트 중앙 $1 / 2$ 지점의 $\mathrm{BG} 2$ 에서는 151.64 $\mathrm{kN}$ 으로 설계 긴장력 대비 $1.95 \%$ 작은 값이 계측되었다.

도입 긴장력을 계측한 결과로 부터 긴장력 도입과정에서 인 장기를 정밀하게 제어하지 못하는 문제로 인하여 설계긴장력 과 계측긴장력의 차이가 $5 \%$ 이상 발생하였다. 따라서 긴장력 을 도입시 시방서 기준인 $5 \%$ 이내 즉시손실을 만족시키기 위 해서는 긴장장비의 정밀한 제어가 필요할 것으로 판단된다. 또 한, $\mathrm{BG} 2$ 계측결과에서는 단부 긴장력 대비 $7 \%$ 이상의 긴장력 손실이 계측되었다. 이는 파상마찰력에 의한 손실과 시공 중 덕트 내부 강연선들의 꼬임 등에 의한 것으로 사료된다.
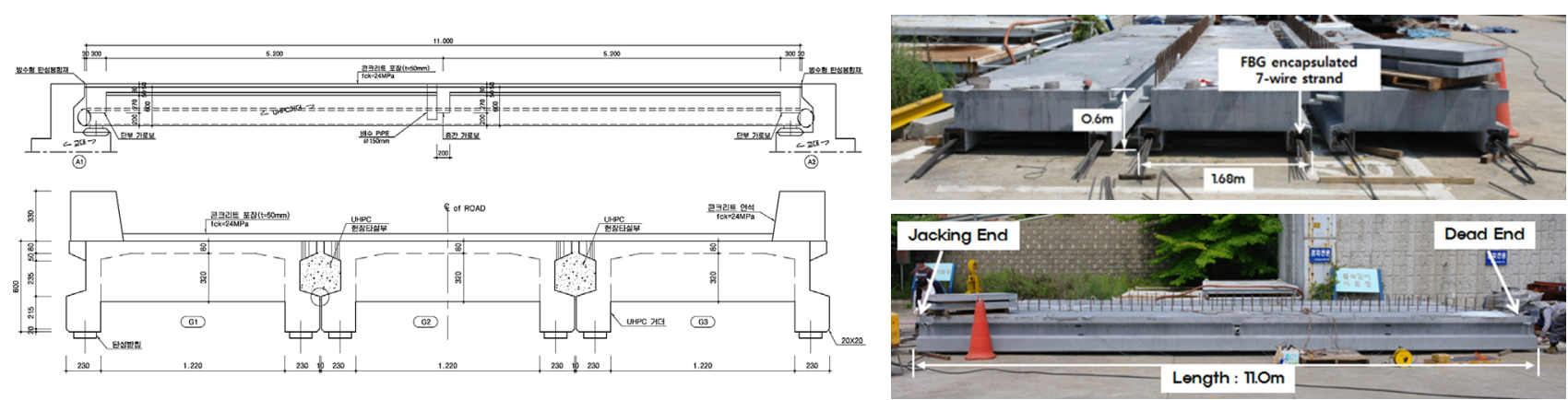

Fig. 5 Dimensions of the UHPC bridge 


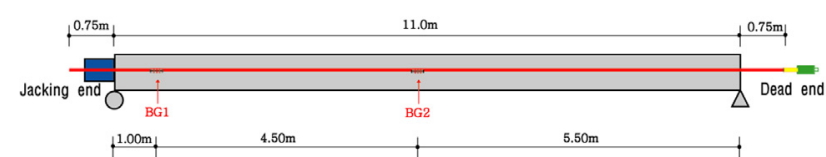

Fig. 7 Installation location of the FBG sensor

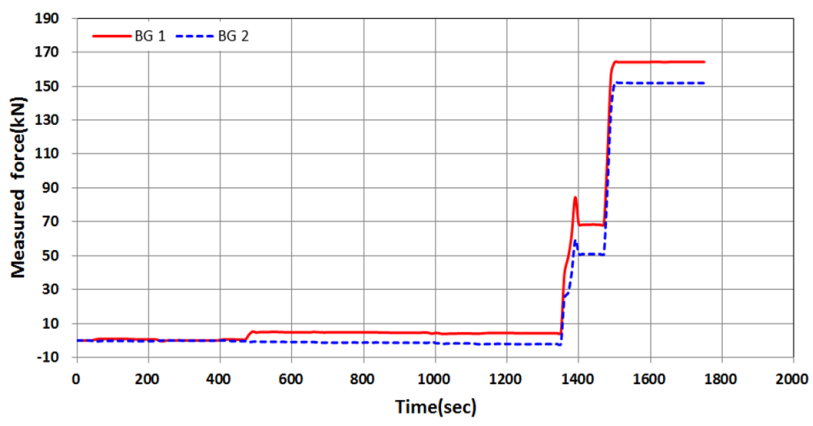

Fig. 8 Monitoring results during the initial prestressing process

\section{3 모니터링 시스템 구축}

광섬유센서는 파손이 쉽게 일어나므로 실제 구조물에 적용 할 경우 많은 어려움이 있다. 이러한 점을 보완하여 $\mathrm{FBG}$ 센 서를 SHM에 적용할 때에는 센서 및 센서단부에 대한 적절 한 보호가 이루어져야 한다. 이에 이 연구에서는 초기 긴장 력 도입 완료 후 $\mathrm{FBG}$ 센서가 내장된 7연 간연선의 단부를 절단하고, 단부 $\mathrm{FBG}$ 센서를 연성이 우수한 공압튜브와 강재 주름관을 이용하여 2중 보호 후 설치현장으로 이동하여 시공 하였다. 또한, 현장시공 완료 후 $\mathrm{FBG}$ 센서의 효율적인 계측 을 위해 광섬유용착기(fiber optic splice)를 이용하여 광점 퍼코드를 연결하고 설치 계측함체까지 지중매설하여 계측시스 템을 구축하였다(Fig. 9). 계측함체는 Fig. 9(d)와 같으며 $\mathrm{FBG}$ 센서 계측을 위한 인터로게이터(interrogator)와 데이터 저장을 위한 컴퓨터, 디지털 온도계 등으로 구성되어 있다.

\section{4 현장재하시험}

이 연구에서 제안하고 있는 콘크리트 내부 긴장력 계측방
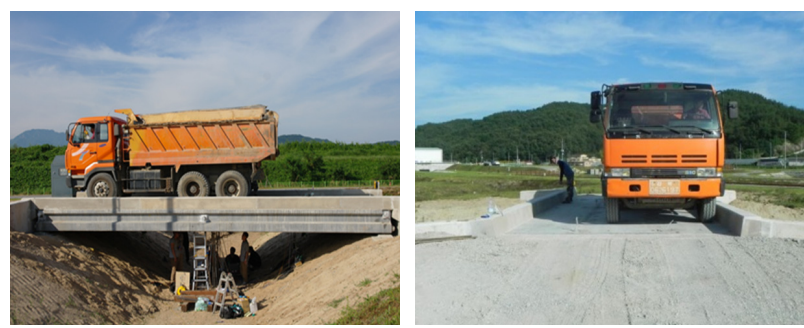

Fig. 10 View of the vehicle loading test

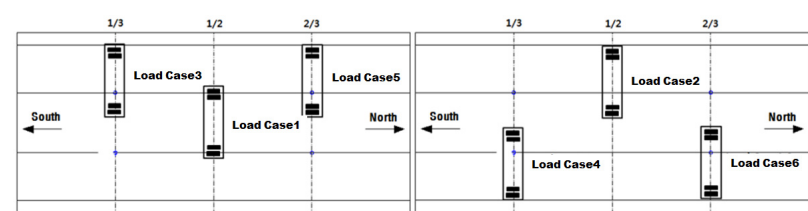

Fig. 11 Overview of the static loading test

법의 효율성을 검증하기 위해 Fig. 10 과 같이 재하시험을 수행하였으며, 재하시험은 차량 가속구간에 대한 공간 확보 의 어려움이 있어 정적재하시험만 진행하였다.

정적재하시험은 Fig. 11 과 같이 교축방향 $1 / 3,1 / 2,2 / 3$ 지점에 차량의 중륜과 후륜이 중앙에 위치하도록 재하하였으 며, $\mathrm{FBG}$ 센서로부터 계측된 온도보정 전 긴장력 계측결과를 정리하면 Fig. 12와 같다. 각 Load Case $(\mathrm{LC})$ 에 대한 차량 하중에 의한 내부 긴장력 변화량은 $\mathrm{LC} 1$ 과 LC 2 에서는 각각 $+2.34 \mathrm{kN},+2.67 \mathrm{kN}$ 이었으며, $\mathrm{LC} 3 \sim \mathrm{LC} 6$ 에서는 +1.89 $\mathrm{kN} \sim 1.39 \mathrm{kN}$ 의 변화를 보였다. 이 결과로부터 차량하중에 의해 계측된 긴장력은 공용 중 긴장력에 비해 매우 작고, FBG센서 위치에서는 인장응력이 발생함을 알 수 있었다.

또한, 장기성능을 확인하기 위해 1 년 동안 약 6 개월 간격 으로 총 3 회의 재하시험을 수행하였으며, 재하시험 시기와 차량 중량은 Table 2 와 같다. 그리고 $\mathrm{FBG}$ 센서 내장 강연선

Table 2 Vehicle weight of load test

\begin{tabular}{|c|c|c|c|c|}
\hline \multirow{2}{*}{ Load test } & \multicolumn{3}{|c|}{ Weight $(\mathrm{kN})$} & \multirow{2}{*}{ Remarks } \\
\cline { 2 - 5 } & Total & Front wheel & Near wheel & \\
\hline 1st & 311.1 & 69.1 & 242.0 & 2012.08 \\
\hline 2nd & 294.9 & 74.3 & 220.3 & 2013.01 \\
\hline 3rd & 294.9 & 68.2 & 226.7 & 2013.08 \\
\hline
\end{tabular}

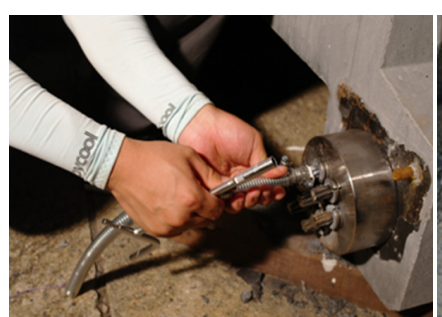

(a) Strand cutting and edge protection

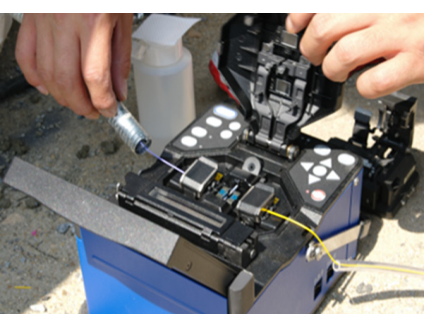

(b) Optical jumper cord connection

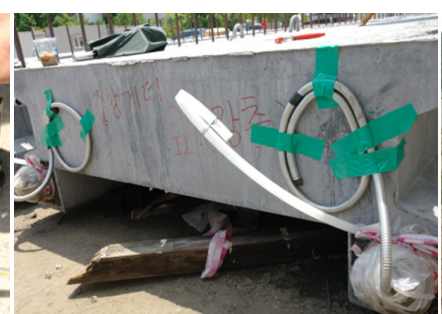

(c) Sensor protection

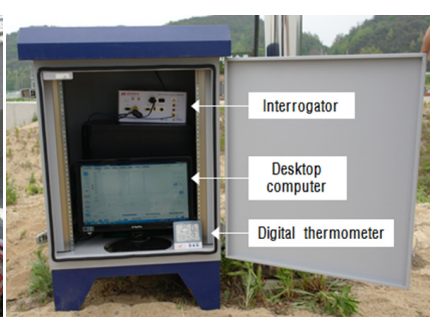

(d) Install monitoring systems

Fig. 9 Long-term monitoring system 


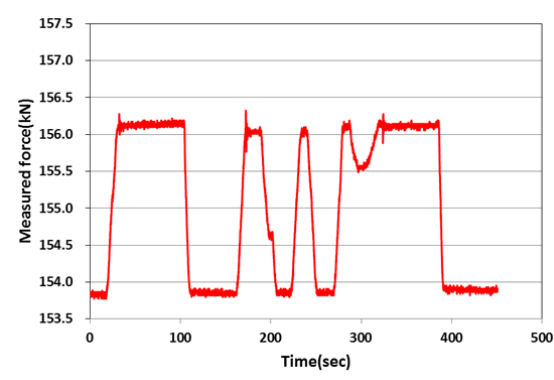

(a) LC 1

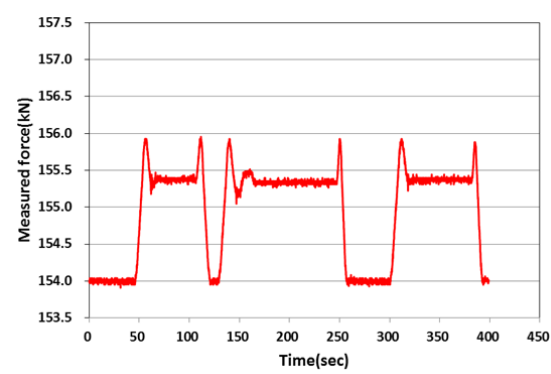

(d) LC 4

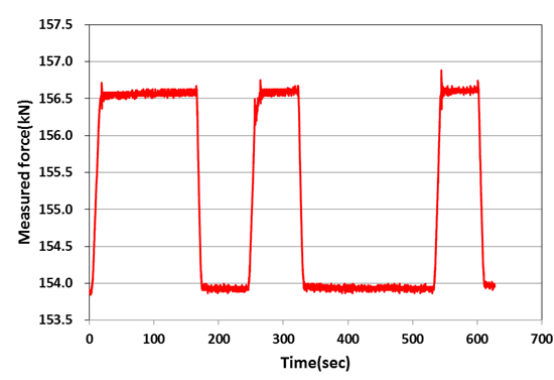

(b) LC 2

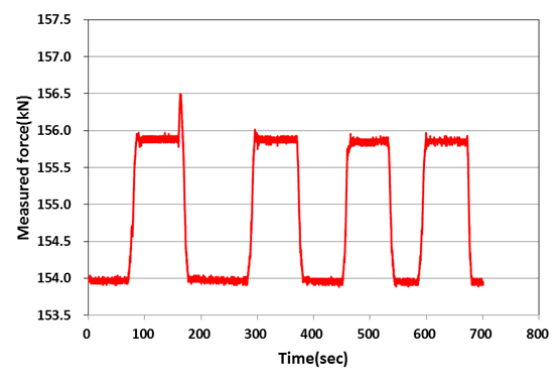

(e) LC 5

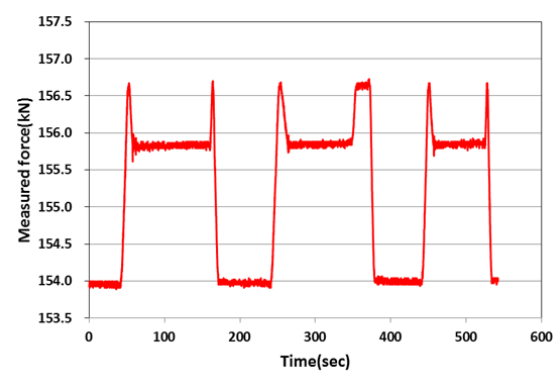

(c) LC 3

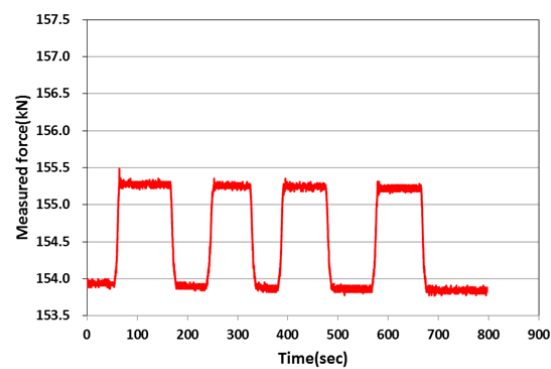

(f) LC 6

Fig. 12 Monitoring results of the first static loading test(Temperature $33.8^{\circ} \mathrm{C}$ )

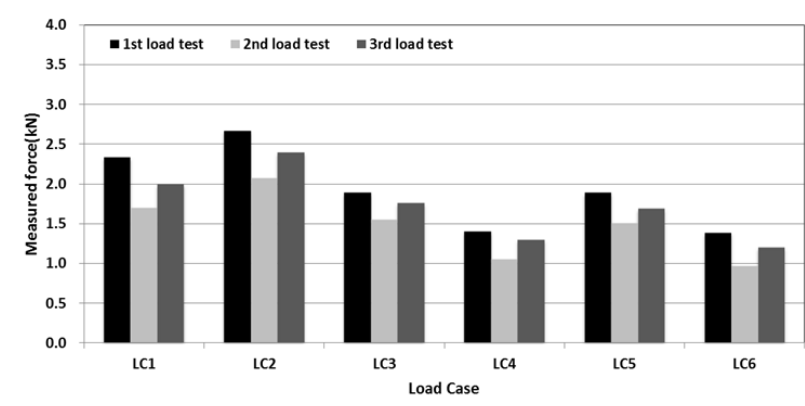

Fig. 13 Tension force variation with vehicle loading

을 이용하여 차량하중 재하에 의한 긴장력의 변화량을 계측 한 결과, Fig. 13 과 같이 차량 통과시 긴장력 변화는 초기긴 장력 대비 $1 \%$ 내외로서 매우 작은 것으로 나타났다.

\section{5 장기모니터링 및 온도보정 결과 고찰}

$\mathrm{UHPC}$ 교량의 장기적인 긴장력 관리를 위해 시공단계별 긴장력을 계측하고, 현장시공 완료 후 장기모니터링시스템을 구축함으로써 재하시험 등 약 1 년 동안의 대기온도와 장기적 인 내부 긴장력 변화를 계측하였다. Fig. 14 는 이 같은 긴장 력 계측결과를 정리한 결과이다. 이 결과에 도시한 바와 같 이 BG1은 긴장력 도입 완료 후 설치현장 이동 도중 외부충 격에 의해 파손되어 센서 기능을 상실하였다. 하지만 BG2는 재하시험 후에도 동일한 계측 값을 보였으며 약 1 년 동안 성 공적인 모니터링 결과를 나타냈다.

$\mathrm{FBG}$ 센서를 이용한 장기모니터링에서는 2.3절에서 설명한 바와 같이 온도의 영향이 크므로 온도보정이 필요하다. $\mathrm{FBG}$
센서를 내장한 강연선은 교량의 거더와 일체화되어 있어 실 내실험 조건과 다르므로 $\mathrm{FBG}$ 센서 자체의 열팽창계수 $\left(\alpha_{F B G}\right)$ 를 온도보정에 적용하기는 어렵다. 즉, 강연선이 거더와 일체 화 되어 있고 거더의 열팽창 거동은 콘크리트가 지배적임을 감안하면 열팽창 시 강연선 내부 $\mathrm{FBG}$ 센서는 콘크리트와 동 일할 것으로 예상할 수 있다. 이 같은 점을 고려하여 이 연 구에서는 식 (2)의 $\mathrm{FBG}$ 센서 열팽창계수로 $\mathrm{UHPC}$ 의 열팽창 계수인 $\alpha_{P S C}=1.35 \times 10^{-6} /{ }^{\circ} \mathrm{C}$ 를 고려하였다. 이 연구에서 검 토한 온도보정 방법은 다음과 같은 네 가지이다.

$$
\begin{aligned}
& M 1: \Delta \varepsilon=\frac{1}{1-P_{e}}\left(\frac{\Delta \lambda}{\lambda_{b}}\right) \\
& M 2: \Delta \varepsilon=\frac{1}{1-P_{e}}\left(\frac{\Delta \lambda}{\lambda_{b}}-\left(\alpha_{F B G}+\xi_{\text {textbook }}\right) \Delta T\right) \\
& M 3: \Delta \varepsilon=\frac{1}{1-P_{e}}\left(\frac{\Delta \lambda}{\lambda_{b}}-\left(\alpha_{P S C}+\xi_{\text {textbook }}\right) \Delta T\right) \\
& M 4: \Delta \varepsilon=\frac{1}{1-P_{e}}\left(\frac{\Delta \lambda}{\lambda_{b}}-\left(\alpha_{P S C}+\xi_{F B G}\right) \Delta T\right)
\end{aligned}
$$

여기서, $M 1$ 은 온도보정 전 유효변형률이며 $M 2, M 3, M 4$ 는 서로 다른 열팽창계수와 열광학계수를 이용한 온도보정방 법이다.

위와 같은 네 가지 방법에 의한 온도보정을 수행하여 긴장 력을 계측한 결과, 대기온도에 의한 온도보정 후(Fig. 14에 서 T.C.BG2)에는 온도보정 전(Fig. 14에서 BG2)의 결과 보다 일관된 긴장력 계측값을 보이고 있다. 특히 $M 3$ 과 $M 4$ 


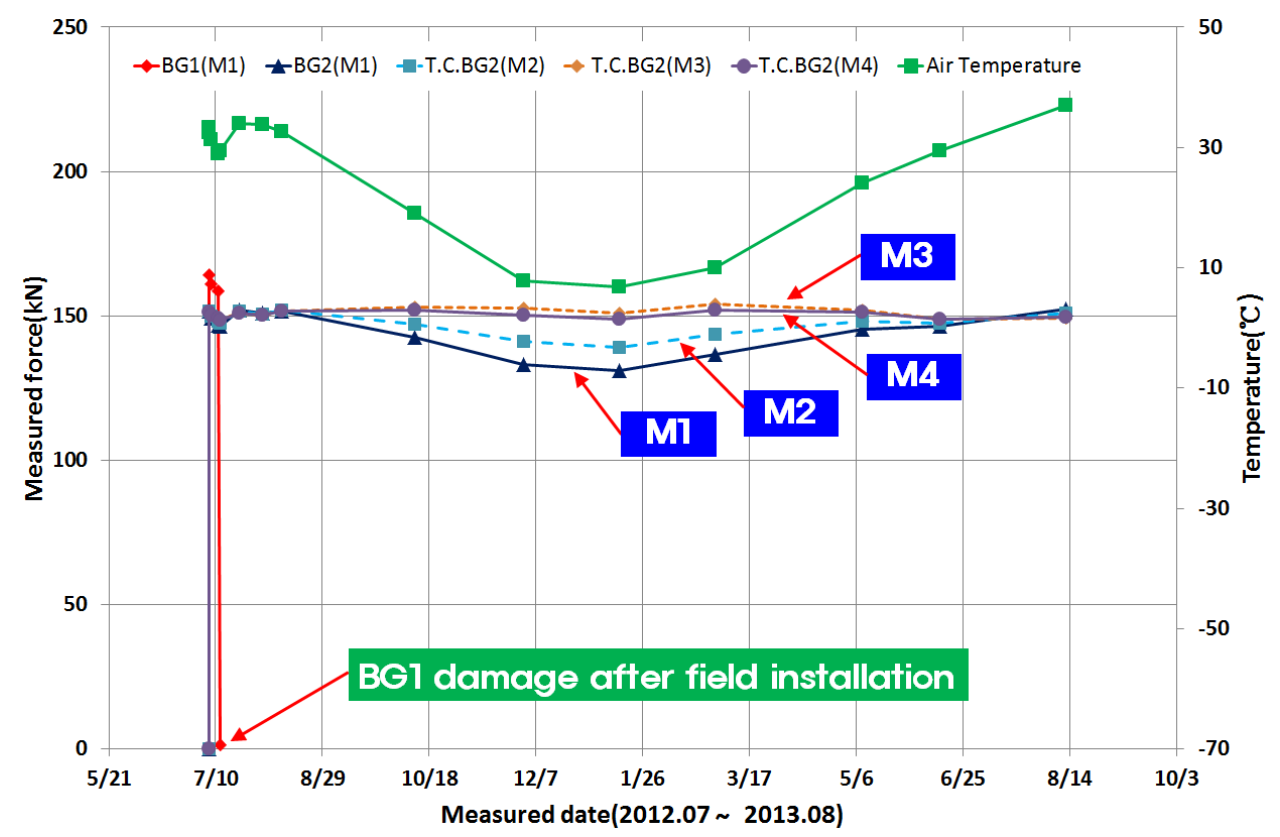

Fig. 14 Long-term monitoring results for one year

방법에 의한 긴장력 계측결과가 외부온도와 상관없이 일정한 값을 보여 실무에 적용 가능한 방법으로 판단된다. 또한 $M 2$ 방법을 적용할 경우 $\mathrm{FBG}$ 센서에 의한 긴장력 계측값의 오차 가 큼을 알 수 있었다. 이로부터 $\mathrm{FBG}$ 센서를 이용한 강연선의 유효변형률 계측을 위한 온도보정을 위해서는 $\mathrm{FBG}$ 센서가 부 착되는 부재의 열팽창계수(이 연구에서는 UHPC의 열팽창계 수 $\left.\alpha_{P S C}\right)$ 를 적용하는 것이 매우 중요한 것으로 나타났다.

\section{4. 결 론}

이 연구에서는 $\mathrm{FBG}$ 센서가 내장된 7연 강연선을 이용하여 포스트텐션 UHPC 교량의 종방향 긴장재 긴장력에 대한 장 기모니터링을 실시하였다. 그리고 이 연구에서 제안하는 강 연선 긴장력 계측방법의 시공 중, 차량재하시험 및 공용 중 장기계측 성능과 $\mathrm{FBG}$ 센서의 온도보정 방법에 대해 고찰하 였다. 연구결과를 정리하면 다음과 같다.

(1) 초기 도입 긴장력은 긴장 장비의 정밀한 제어가 어려 울 경우 $5 \%$ 이상의 순간손실이 발생할 수 있음을 확 인하였으며, 직선으로 배치된 강연선들 사이에서도 파 상마찰 및 강연선들 간의 꼬임으로 인해 양단에서 긴 장력 차이가 $7 \%$ 이상 발생할 수 있음을 발견하였다.

(2) 교량 완공 후 실시한 차량재하시험을 통하여 콘크리 트 내부 긴장부재의 긴장력 측정이 가능하였으며, 1 년 간 장기계측을 통하여 이 연구에서 제안하는 $\mathrm{FBG}$ 센서를 이용한 포스트텐션 강연선의 긴장력 계측방법
의 적용성을 입증하였다.

(3) 교량의 $\mathrm{FBG}$ 센서 장기모니터링 계측결과와 대기온도 정보를 활용하여 현장에 설치된 교량의 강연선 긴장 력을 평가한 결과, $\mathrm{FBG}$ 센서를 이용한 구조물의 장기 모니터링에서는 온도보정을 수행하지 않을 경우 대기 온도 변화에 따라 $10 \%$ 이상의 긴장력 증감으로 판단 할 수 있으므로 온도보정이 매우 중요함을 알 수 있 었다. 아울러 이 연구에서 제안한 온도보정 방법의 유 효성도 입증되었다.

\section{감사의 글}

이 연구는 국토교통과학기술진흥원 창의도전연구(14CTAP -C078424-01) 및 한국건설기술연구원의 주요사업(No. 2010 -0018920)의 연구비 지원을 받아 수행되었습니다.

\section{References}

Calvert, S., Mooney, J. (2004) Bridge Structural Health Monitoring System using Fiber Grating Sensors: Development and Preparation for a Permanent Installation, SPIE Proc., 5391, pp.61 71.

Hong, C.S., Ryu, C.Y., Koo, B.Y., Kim, C.G., Yun, S.H. (2000) Strain Monitoring of Smart Bridge using Fiber Bragg Grating Sensor System with Wavelength-Swept Fiber Laser, SPIE Proc., 3988, 
pp.371 379.

Inaudi, D. (2009) Overview of 40 Bridge Structural Health Monitoring Projects, International Bridge Conference, IBC 2010.

Kim, S.T., Park, Y.H., Park, Y.H., Cho, K.H., Cho, J.R. (2015) A Sensor-Type PC Strand with an Embedded FBG Sensor for Monitoring Prestress Forces, Sensors, 15, pp.1060 1070.

Kim, J.M., Kim, H.W., Park, Y.H., Kim, Y.S. (2010) Tension Monitoring of a Prestressing Strand for Concrete Bridge using In-Tendon FBG Sensors, Proc. IABMAS-2010, pp.205 210.

Kim, J.M., Kim, H.W., Park, Y.H., Yang, I.H., Kim, Y.S. (2012) FBG Sensors Encapsulated into 7-Wire Steel Strand for Tension Monitoring of a Prestressing Tendon, Adv. Struct. Eng., 15(6), pp.907 918.

Lau, K.T. (2003) Fibre-Optic Sensors and Smart Composites for Concrete Applications, Mag. Concr. Res., 55(1), pp.19 34.

Nellen, P.M., Bronnimann, R., Frank, A., Mauron, P., Sennhauser, U. (1999) Structurally Embedded Fiber Bragg Gratings: Civil Engineering Application, SPIE Proc., 3860, pp.44 54.

Maaskant, R., Alavie, T., Measures, R.M., Tadros, G., Rizkalla S-H., Guha-Thakurta, A. (1997) Fiber-Optic Bragg Grating Sensors for Bridge Monitoring, Cement and Concrete Composites, 19(1), pp. $21 \sim 33$.
Othonos, A., Kalli, K. (1999) Fiber Bragg Gratings, Artech House, London.

Ren, L., Li, H.N., Sun, L., Li, D.S. (2005) Development of Tube-Packaged FBG Strain Sensor and Application in the Vibration Experiment of Submarine Pipeline Model. SPIE Proc., pp.98 103.

Tennyson, R.C., Mufti, A.A., Rizkalla, S., Tadros, G., Benmokrane, B. (2001) Structural Health Monitoring of Innovative Bridges in Canada with Fiber Optic Sensors, Smart Mater. \& Struct., 10(3), pp. $1 \sim 22$.

Udd, E. (1996) Fiber Optic Smart Structures, John Wiley and Sons, Inc.

Xuan, F.Z., Tang, H., Tu, S.T. (2009) In Situ Monitoring on Prestress Losses in the Reinforced Structure with Fiber-Optic Sensors, Measurement, 42(1), pp.107 111.

Zhou, Z., Zhang, Z., Deng, N., Zhao, X., Li, D., Wang, C., OU, J. (2005) Applications of FRPOFBG Sensors on Bridge Cables, SPIEProc., pp.668 677.

Zhou, Z., OU, J. (2004) Development of FBG Sensors for Structural Health Monitoring in Civil Infrastructures, Sensing Issues in Civil Structural Health Monitoring, pp.197 207.

Zhang, Z., Zhou, Z., Wang, C., Ou, J. (2006) Long-Term Monitoring FBG-Based Cable Load Sensor, SPIE Proc., 6167, pp.1 7.

이 연구에서는 $\mathrm{FBG}$ 센서가 내장된 강연선을 포스트텐션 $\mathrm{UHPC}$ 교량(길이 $11.0 \mathrm{~m}$, 폭 $5.0 \mathrm{~m}$, 높이 $0.6 \mathrm{~m}$ )에 적용하고 약 1년 간의 긴장력 장기모니터링 결과를 정리하였다. 그리고 초기 도입 긴장력과 차량재하시험을 통하여 콘크리트 내부 강연선의 긴장력 변화를 계측하고 계측결과에 대한 분석을 수행하였다. 연구결과, 이 연구에서 제안하는 콘크리트 내부 긴장력 측정 방법이 공영 중인 교량에서 외력으로 인한 콘크리트 내부의 작은 프리스트레스 변화를 효과적으로 측정할 수 있음을 알 수 있었다. 아울러 장기 계측결과를 이용하여 응력변화에 의한 유효변형률을 정확하게 얻기 위해서는 온도보정에 사용되는 열 팽창계수의 선택이 매우 중요함을 알 수 있었다.

핵심용어 : FBG센서, $\mathrm{PSC}$ 거더, 프리스트레스 강연선, 긴장력 모니터링, 온도보정 